\title{
COMMUNICATIVE RISKS RELATED TO UNJUSTIFIED USE OF BORROWINGS IN MODERN MEDIA
}

\author{
Evgenia V. Gulyaeva \\ Volgograd Institute of Management, branch of the Russian Presidential Academy \\ of National Economy and Public Administration (RANEPA), Volgograd, Russia \\ Maria V. Denisenko \\ Volgograd Institute of Management, branch of the Russian Presidential Academy \\ of National Economy and Public Administration (RANEPA), Volgograd, Russia \\ Irina S. Nikitina \\ Volgograd Institute of Management, branch of the Russian Presidential Academy \\ of National Economy and Public Administration (RANEPA), Volgograd, Russia
}

\begin{abstract}
The article deals with the problem of native speakers understanding of the latest borrowings actively introduced into speech practice by mass media. The authors describe the reasons for the spread of borrowings, and pay special attention to the pragmatic, as well as social-and-psychological factors that affect this process. Based on the results of the pilot experiment conducted by the authors, it was found out that the majority of respondents, who are native speakers of the Russian language, either do not understand the meaning of anglicisms that are frequent in the modern media or only approximately interpret it, which allows the authors to speak about the agnonymy of this vocabulary. The analysis of modern media texts was aimed at selecting borrowed vocabulary for its further inclusion in the questionnaire, followed by a pilot experiment, which focused on interpretation of the meanings of the latest anglicisms used in the media. The accuracy of recipients comprehension of foreign words meaning used in the media varies depending on their age, occupation, and interests. Thus, news addressed to mass audience should not contain anglicisms so as to prevent communicative failures. The authors describe the communicative risks associated with misinterpretation of information presented in the media, and outline ways to overcome the negative impact of borrowings associated with it.

Key words: borrowings, communicative risks, global English, anglicisms, media language, agnonyms.

Citation. Gulyaeva E.V., Denisenko M.V., Nikitina I.S. Communicative Risks Related to Unjustified Use of Borrowings in Modern Media. Vestnik Volgogradskogo gosudarstvennogo universiteta. Seriya 2. Yazykoznanie [Science Journal of Volgograd State University. Linguistics], 2021, vol. 20, no. 1, pp. 146-157. (in Russian). DOI: https://doi.org/10.15688/jvolsu2.2021.1.12

\section{УПОТРЕБЛЕНИЕ ЗАИМСТВОВАНИЙ В СОВРЕМЕННЫХ СМИ: КОММУНИКАТИВНЫЕ РИСКИ}

\section{Евгения Вячеславовна Гуляева}

Волгоградский институт управления - филиал Российской академии народного хозяйства и государственной службы при Президенте РФ, г. Волгоград, Россия

\section{Мария Валерьевна Денисенко}

Волгоградский институт управления - филиал Российской академии народного хозяйства и государственной службы при Президенте РФ, г. Волгоград, Россия 
Е.В. Гуляева, М.В. Денисенко, И.С. Никитина. Употребление заимствований в современных СМИ

\section{Ирина Сергеевна Никитина}

Волгоградский институт управления - филиал Российской академии народного хозяйства и государственной службы при Президенте РФ, г. Волгоград, Россия

Аннотация. Статья посвящена проблеме понимания носителями языка новейших заимствований, активно внедряемых в речевую практику средствами массовой информации. Охарактеризованы причины распространения заимствований, особое внимание уделено прагматическим и социально-психологическим факторам, влияющим на этот процесс. На основе результатов проведенного авторами пилотного эксперимента установлено, что значение англицизмов, частотных в современных СМИ, большинство респондентов - носителей русского языка либо не понимают, либо интерпретируют приблизительно, что позволяет говорить об агнонимичности этой лексики. Е.В. Гуляевой разработана концепция исследования, охарактеризован его терминологический аппарат, обобщены результаты эксперимента. М.В. Макаровой и И.С. Никитиной осуществлены анализ текстов современных средств массовой информации и отбор заимствованной лексики для составления анкеты, проведен пилотный эксперимент, ориентированный на интерпретацию значений новейших англицизмов, использованных в СМИ. Авторами определены коммуникативные риски, связанные с интерпретацией информации, транслируемой в СМИ, намечены пути преодоления негативного влияния заимствований и предупреждения коммуникативных неудач.

Ключевые слова: заимствование, коммуникативный риск, глобальный английский, англицизм, язык СМИ, агноним.

Цитирование. Гуляева Е. В., Денисенко М. В., Никитина И. С. Употребление заимствований в современных СМИ: коммуникативные риски // Вестник Волгоградского государственного университета. Серия 2, Языкознание. -2021. - Т. 20, № 1. - C. 146-157. - DOI: https://doi.org/10.15688/jvolsu2.2021.1.12

\section{Введение}

Характерной чертой современной языковой ситуации можно назвать рост количества заимствований и их интенсивное проникновение во все сферы коммуникации. У этого есть объективные причины: известно, что активизация заимствования лексики из других языков наблюдается в периоды бурных социальных, экономических и политических изменений в обществе, связана с появлением новых реалий и неизбежным взаимопроникновением культур. Обратной стороной этого процесса становится нарушение понятийной точности, непонимание или искаженное восприятие информации в процессе общения, а также снижение общего уровня языковой культуры носителей языка-реципиента.

Активное проникновение англицизмов в лексикон носителя русского языка происходит, несомненно, при участии средств массовой информации, которые, отвечая вызовам современного общества, используют заимствования, зачастую лексически избыточные или же непонятные большей части населения. Это неизбежно ведет к коммуникативным неудачам, которые В.Д. Черняк определила как «неосуществление или неполное осуществление коммуникативных намерений говорящего (полное или частичное непонимание), нежелательный эмоциональный эффект» [Черняк, 2005, с. 96]. С понятием коммуникативных неудач связано понятие коммуникативных рисков, то есть особенностей речи, «которые могут вызвать недопонимание в процессе общения, стать причиной конфликта. Подобные риски возникают в процессе коммуникации среди прочего как из-за заимствованных языковых явлений в другие языки, так и по причине изменений в самом языке» [Гуляева, 2018, с. 146].

Целью предпринятого нами исследования стало описание коммуникативных рисков, а именно: полное или частичное непонимание смысла информационного сообщения, его неправильная интерпретация, семантическая «пустота» текста для читающего и слушающего, возникающая при неоправданном использовании англоязычной заимствованной лексики в современных СМИ, а также определение степени освоенности и понимания наиболее распространенных англоязычных терминов и лексем современными носителями русского языка.

\section{Материал и методы}

Проблема влияния заимствований на современный русский язык находится в фокусе 
внимания исследователей на протяжении двух последних десятилетий и не теряет своей актуальности. В условиях глобализации, постоянного взаимопроникновения культур и использования английского языка в качестве средства международного общения такое влияние становится все более заметным в силу расширения сфер применения специальной иноязычной терминологии из области экономики, политики, финансовой деятельности. Многиезаимствования, относящиеся к последним десятилетиям XX в., изменили свой функциональный статус, став неотьемлемой частью тезауруса образованного носителя русского языка. В то же время новейшие заимствования начала XXI в. (около 30 тыс. за последние 15 лет) составляют объект развернувшихся научных дискуссий, зачастую воспринимаются носителями языка как «инородные элементы», оказывающие негативное влияние на русскую речевую культуру [Козырев, Черняк, 2007, с. 54]. В.И. Карасик отмечает, что за активным процессом заимствования лексики другого языка всегда стоит «внедрение в иную культуру концепта ментального образования, опирающегося на многослойный культурный опыт, сконцентрированный в индивидуальном и коллективном языковом сознании» [Карасик, 2002, с. 177]. Исследуя природу заимствований, Л.П. Крысин определяет их как «единицы чужого языка, вошедшие в лексико-семантическую систему языка-реципиента» [Крысин, 2004, с. 24], в отличие от экзотической лексики и иноязычных вкраплений, которые, по мнению ученого, не принадлежат системе использующего их языка, не функционируют в нем в качестве более или менее прочно связанных с лексическим и грамматическим строем этого языка единиц [Крысин, 2004, с. 19].

К основным причинам, по которым носители русского языка отдают предпочтение англицизмам в разных сферах коммуникации, лингвисты относят прежде всего прагматические установки говорящего и пишущего. По мнению исследователей, наиболее жизнеспособны те заимствования, которые способствуют экономии языковых средств. Например, Н.С. Гуторова пишет: «Если одно слово аутсорсинг (здесь и далее в цитате курсив наш. - Авт.) заменяет целую фразу “выполнение всех или части функиий по управле- нию организацией сторонними спещчиалистами”, то оно вполне жизнеспособно. Это относится не только к терминам типа франчайзинг, но и к обыденным словам типа рейтинг, грин-кард, и даже супермаркет. Таким образом, наиболее оправданны заимствования, которые заполняют прагматические лакуны» [Гуторова, 2015, с. 102]. В.А. Козырев и В.Д. Черняк также отмечают, что «одной из причин многочисленных заимствований является тенденция к аналитизму - замене словосочетания одним словом, таким образом реализуется закон языковой экономии: саммит "встреча, переговоры глав государств, правительств”, праймтайм - “лучшее время на телевидении”, электорат - “круг избирателей, голосующих за какую-нибудь кандидатуру или за политическую партию на парламентских, президентских и муниципальных выборах”» [Козырев, Черняк, 2007, с. 55].

В научной литературе охарактеризованы и другие лингвистические причины заимствований. Л.П. Крысин, кроме стремления к экономии языковых средств, замене одночленным компонентом многочленных, выделяет также стремление к устранению многозначности исконно русского слова, к изменению его семантической структуры; потребность в прояснении и детализации определенного явления или понятия, в разграничении некоторых смысловых оттенков (ср. аудит - проверка); стремление к формированию структурно аналогичных слов [Крысин, 2004, с. 201].

Именно прагматические установки лежат, по мнению лингвистов, в основе широкого использования заимствований в СМИ: «активное пополнение терминолексики за счет англицизмов связано с необходимостью подведения политических и экономических номинаций под единые общемировые стандарты. Новое иноязычное слово всегда прагматически отмечено, поскольку в комплексе причин заимствования, помимо когнитивных факторов, большую роль играют прагматические стимулы. По мере конвенциализации неологизма иноязычного происхождения происходит постоянное перераспределение прагматических компонентов его содержания» [Китанина, 2005 , с. 32$]$; «типичным примером увеличения кода является заимствование иноязычных слов для передачи понятий, которые без ино- 
язычного слова можно обозначить только описательно. Именно этот путь разрешения антиномии кода и текста оказывается преобладающим в начале XXI в.» [Китанина, Божинская, 2009, с. 239].

Кроме лингвистических причин исследователями отмечаются и социально-психологические причины заимствований. В понимании носителей языка иностранные слова в речи звучат более престижно и воспринимаются как часть элитарной культуры. «Один из источников привлекательности иностранного слова, - считает И.Т. Вепрева, - экзотичность формы. Культурно отдаленное, “чужое” для модного объекта всегда позитивно окрашено. Эта удаленность как бы компенсирует временную близость. Поэтому в корпусе модных слов представлены преимущественно новые заимствованные слова, которые в соединении с субъективным ощущением новизны придают слову эстетическую модальность необычности слова» [Вепрева, 2006, с. 116-117].

Пристрастие к заимствованиям, являющееся одной из отличительных черт «полуобразованного владения языком, соединенного с плохим владением мыслью и логикой» [Апресян, 1992, с. 51], часто соединяется в современной речи с непониманием заимствований при восприятии и квазизнанием - при порождении [Козырев, Черняк, 2007, с. 54].

Именно социально-психологическими причинами ученые объясняют многие коммуникативные неудачи при использовании заимствований в речи.

Лингвистические исследования последних десятилетий подтверждают сложившуюся в современном обществе тенденцию к неосознанному использованию новых иноязычных слов как среднестатистическими носителями языка, так и представителями СМИ, которые зачастую не понимают значения употребляемых заимствований или неверно их интерпретируют. В результате неосознанного включения иноязычных слов в текст информационного сообщения неизбежно возникает семантическая «глухота», поскольку материал, содержащий неизвестную для читающего или слушающего лексику, остается непонятым и пустым. Особенно ярко это наблюдается на примере новых заимствований, которые еще не зафиксированы в словарях или справочни- ках, но регулярно воспроизводятся в текстах СМИ и разговорной речи, оставаясь неосознанными [Граудина и др., 1995, с. 80].

Неизвестные или недостаточно понятные, нечетко осознаваемые носителями языка лексические единицы получили в исследованиях В.В. Морковкина и А.В. Морковкиной наименование «агноним» [Морковкин, Морковкина, 1997, с. 23]. Изучение агнонимов позволяет проанализировать глубинные речемыслительные процессы, выявить способы фиксации новых значений слов в сознании носителей языка, установить, каким образом происходит связывание трех компонентов (знак, значение, денотат) в единую структуру. Авторы термина предлагают считать агнонимичной лексической единицей (слово или отдельное его значение) ту, относительно которой носитель языка может сказать: 1) «совершенно не знаю, что значит слово»; 2) «имею представление только о том, что слово обозначает нечто, относящееся к определенной весьма широкой сфере»; 3) «знаю, что слово обозначает нечто, относящееся к определенному классу предметов, но не знаю, чем именуемый предмет отличается от других предметов данного класса»; 4) «знаю, что слово обозначает определенный предмет, но не знаю конкретных особенностей этого предмета, способов его использования или функционирования»; 5) «знаю, что обозначает слово, но не представляю, как выглядит соответствующий предмет»; 6) «знаю слово в связи с особенностями своего жизненного опыта и своей специальности, но предполагаю, что многие другие люди его не знают или знают недостаточно» [Морковкин, Морковкина, 1997, с. 106].

Ученые, исследовавшие агнонимы, отмечают, что популяризация средствами массовой информации экономической, общественнополитической, медицинской, компьютерной, финансовой терминологии постепенно ведет к активному проникновению этой лексики в тезаурусы носителей языка, но при этом наблюдается заметное снижение культуры письменной и устной речи, вызванное преобладанием в речи разговорной и жаргонной лексики, проникновением ее в книжные стили языка, а также заметным влиянием интернеткоммуникации на процесс общения. Значи- 


\section{МАТЕРИАЛЫ И СООБЩЕНИЯ}

тельную роль в этом процессе играют именно заимствования, которые являются агнонимичными для большинства среднестатистических носителей языка.

Общественно-политическая лексика, активно используемая в средствах массовой информации, также становится агнонимичной, поскольку большая часть зрителей и читателей воспринимает ее только в рамках заданного контекста, не вдаваясь в анализ семантической структуры [Пентина, Черняк, 2015, с. 189].

Журналисты зачастую злоупотребляют использованием заимствований, не учитывая того факта, что такие слова могут быть не поняты потенциальными адресатами. Говоря о характерной для современной языковой ситуации моды на заимствования, О.Б. Сиротинина отмечает, что «обеднение системы и узуального лексикона, а также его засорение создают риск непонимания, легко преодолеваемый в обиходном неофициальном общении, но нередко очень вредящий профессиональному общению, а при намеренном непонимании легко провоцируют и социальные риски, возникающие в общении власти с оппозицией и населением» [Сиротинина, 2013, с. 12].

Опираясь на представленные толкования заимствований, причин их появления и влияния на коммуникацию, мы провели пилотный эксперимент, нацеленный на выявление понимания значений некоторых современных англоязычных заимствований носителями русского языка. В процессе интерпретации полученной информации учитывались важные социальнопсихологические параметры респондентов (пол, возраст, уровень образования, знание иностранных языков, место жительства), поскольку все эти факторы определяют характер лексикона отдельно взятого носителя языка.

За основу исследования взят метод анкетирования. Нами были проанализированы телевизионные программы и интернет-издания («Ведомости», «Известия», информационное агентство «РБК», информационное агентство «TACC», «Russia Today») и отобраны 60 наиболее часто встречающихся заимствований, значение которых было предложено объяснить анкетируемым. В эксперименте приняли участие 240 респондентов. Они были разделены на 4 возрастные группы по 60 человек в каж- дой (15-25 лет, 26-35 лет, 36-45 лет; 4655 лет). Цель эксперимента - определить, носители русского языка какого возраста лучше других ориентируются в потоке англицизмов, употребляемых в современных СМИ, а следовательно, точнее интерпретируют новостные сообщения, содержащие заимствования.

\section{Результаты и обсуждение}

\section{Интерпретация заимствований носителями русского языка}

Приведем некоторые из полученных в ходе опроса ответов. Слова расположены в алфавитном порядке.

Аккаунт - «страница в Интернете с данными об определенном пользователе». Данный англицизм безошибочно смогли объяснить анкетируемые возрастных групп 15-25 лет, 26-35 лет, 36-45 лет - $80 \%$, $86 \%$, 88 \% соответственно. Лишь $38 \%$ респондентов в возрастной группе от 46 до 55 лет не смогли дать определение этому англицизму. $4 \%$ респондентов дали ответ счет: в данных случаях имел место прямой перевод многозначного слова account, однако в русском языке это заимствование употребляется лишь в значении «личный кабинет» (Академик.ру).

Aутсайдер - «находящийся в числе последних, занимающий малозначимое место». Это слово уже давно вошло в обиход носителей русского языка, но далеко не все респонденты справились с объяснением его значения. Так, в группе респондентов 15-26 лет 50 \% участников эксперимента затруднились дать определение рассматриваемому англицизму, при этом среди их ответов встречались такие, как лидирующий; изгой; фрилансер; за пределами нормального, обыденного. В группах респондентов 26-35 лет и 36-45 лет только $10 \%$ информантов затруднились с ответом, среди объяснений встречались такие, как проигравший; отстающий; любитель, неспецииалит; посторонний. В группе респондентов 46-55 лет количество знающих и незнающих значение данного англицизма оказалось одинаковым, в ответах респондентов данной возрастной группы встречались определения: тот, кто с краю и даже успешный. 
Ворк аут - «уличная гимнастика, любительский вид спорта». Несмотря на растущую популярность данного вида спорта среди молодежи, около $40 \%$ респондентов от 15 до 25 лет не смогли объяснить значения этого заимствования, хотя среди ответов представителей данной возрастной группы встречались: спорт в нерабочее время, перерыв; упражнение на силу; вне работы; тренировка; работа на улище; спорт на турниках; физкультура; паркур; законченная работа; конец. Среди респондентов 26-35 лет и 36-45 лет также только $40 \%$ участников эксперимента смогли объяснить значение англицизма. Ответы включали следующие толкования: занятия на турниках, площзакка для интенсивной тренировки, работа вне офиса; практический семинар; удаленная работа; уличные тренажеры. Из респондентов 46-55 лет только 30 \% попытались объяснить значение данного заимствования.

Истеблишмент - «правящие круги, политическая элита». Значение данного англицизма смогли объяснить $35 \%$ респондентов в во3расте 15-26 лет, $20 \%$ респондентов - в возрасте 26-35 лет, около 70 \% респондентов - в возрасте от 36 до 45 лет и от 46 до 55 лет. Среди значений англицизма респонденты называли: власть; правительство; те, кто может голосовать; американские политики, лоббируюшие кого-либо; люди, которые выбирают; политическое объединение.

Контент - «содержательное наполнение информационного ресурса». Как и все термины, связанные с Интернетом, данный англицизм хорошо знаком молодому поколению: почти $80 \%$ респондентов в возрасте от 15 до 25 лет, $65 \%$ респондентов - в возрасте от 26 до 35 лет знают его значение. В группах респондентов 36-45 лет и 46-55 лет только 50 \% информантов смогли объяснить значение данного слова. Определяя значение англицизма, анкетируемые использовали следующие ассоциативные цепочки: текст, картинки, наполнение; основной смысл; продукт деятельности, представляемый материал; популярная тема; жанр.

Саммит - «встреча и переговоры людей, представляющих в своих государствах высшую власть». Появившись в русском языке еще в 1980-х гг., слово саммит, в силу своей лаконичности, вытеснило многосложный русский эквивалент и закрепилось не только в официальном языке, но и в обиходной речи. Возможно, поэтому данное заимствование смогли объяснить $60 \%$ респондентов $15-$ 25 лет, $80 \%$ респондентов 26-45 лет, $100 \%$ респондентов 36-45 лет, более $80 \%$ респондентов 46-55 лет. Отметим, что многие информанты определяют значение англицизма словами переговоры, встреча, собрание без указания статуса участников встречи, однако именно этот признак является ключевым в семантике рассматриваемого заимствования.

Фейк - «фальшивые новости, дезинформация, подделка». Это понятие довольно часто употребляется в интернет-коммуникации в значении «подделка» («фейковый аккаунт» - «поддельная страница»), в СМИ в значении «дезинформация» и знакомо респондентам разных возрастов, что подтверждают результаты анкетирования. Это заимствование весьма частотно в русской речи. Лишь $10 \%$ анкетируемых в трех возрастных группах (15-25, 36-45 и 46-55 лет) не смогли объяснить значения англицизма, в то время как в группе 26-35 лет 100 \% респондентов дали правильные ответы. Знание семантики данного англицизма можно объяснить практически ежедневным упоминанием его в телевизионных и печатных СМИ (в основном в словосочетании фейковые новости), а также, возможно, краткой и, соответственно, легко запоминающейся формой слова.

Харассмент - «преступление, заключающееся в нарушении неприкосновенности частной жизни; назойливое приставание; домогательство с сексуальным подтекстом» (Академик.ру). В группе от 15 до 25 лет лишь $15 \%$ смогли объяснить значение данного англицизма, $70 \%$ в возрастных группах от 25 до 36 и от 36 до 45 лет не смогли объяснить значение данного слова, в группе от 46 до 55 лет количество знающих и незнающих значение данного термина оказалось одинаковым. Среди ответов, данных респондентами, встречались следующие толкования: домогательство, домогательства в рабочем коллективе, недостойное поведение, действия отрицательного влияния, оскорбление, выборы.

Экзит пол - «процедура социологического опроса граждан на выходе из избирательных участков после голосования». Несмотря на весьма частое звучание данного выраже- 


\section{МАТЕРИАЛЫ И СООБЩЕНИЯ}

ния с экранов телевизоров и употребление его в печатных СМИ, более $40 \%$ респондентов 15-25 лет не смогли правильно объяснить его значение, среди респондентов 26-35 и 3645 лет количество незнающих значение оказалось больше $50 \%$, самой неосведомленной оказалась старшая группа - 70 \% респондентов не знали значения данного термина. Среди наиболее частых ответов встречались: опрос, опрос перед выборами, предварительные итоги, встреча с прессой, интервью, результаты голосования.

Анкетирование показало, что, несмотря на частое употребление рассмотренных англицизмов в современных СМИ, бо́льшая часть аудитории неточно определяет их значение. При этом опрашиваемые от 36 до 55 лет лучше ориентируются в заимствованиях из политической и экономической сфер (истеблишмент, харассмент, ритейл), а респонденты в возрасте от 15 до 25 лет могут объяснить англицизмы, связанные с IT-технологиями и сетью Интернет (интерфейс, аккаунт, хайn). Отметим также, что приведенное респондентами толкование слов зачастую свидетельствует о незнании или неточном понимании англицизма, однако опрашиваемые убеждены, что данное слово хорошо ими усвоено, а это неизбежно приводит к ошибочному словоупотреблению, непониманию и коммуникативным неудачам в процессе профессионального или межличностного общения.

\section{Влияние СМИ на процесс ассимиляции заимствованной лексики}

Большое количество заимствований проникает в язык и постепенно ассимилируется в нем благодаря новостным сообщениям, посвященным мировой политике. Это можно объяснить тем, что процесс глобализации уже давно сделал английский языком мирового общения. Однако нам представляется, что в некоторых случаях использование русского эквивалента было бы более уместным для среднестатистического читателя. Проиллюстрируем это предположение примерами использования англицизмов в новостных блоках разной тематики в СМИ (2018-2019 гг.).

Термин Brexit (сокр. от Britain exit - «выход Британии из Европейского союза») был введен в употребление мировыми СМИ в
2016 г. и с тех пор активно используется журналистами. В следующем, небольшом по объему контексте данный термин употребляется несколько раз:

(1) СМИ узнали о тайном обсуждении отсрочки Brexit в британском правительстве. Представители британского кабмина собрались, чтобы обговорить возможность отсрочки Brexit. Выход из ЕС они хотят отложить до 24 мая. Ранее Тереза Мэй называла разговоры о переносе Brexit контрпродуктивными (РБК).

Использование англицизма Brexit в данном случае может быть оправдано экономией языковых средств, лаконичностью выражения мысли и отсутствием эквивалента этого слова в русском языке, но только при условии достижения адекватного понимания данного термина целевой аудиторией.

О высокой плотности англицизмов в российских политических новостях может свидетельствовать следующий пример:

(2) 15 января депутаты Палаты общин отвергли сделку с ЕС об условиях Brexit, а затем позднее одобрили две поправки к биллю о выходе Соединенного Королевства из состава Евросоюза. Они потребовали от правительства избежать Brexit без сделки, а также постановили убрать из текста проекта соглашения с Евросоюзом упоминание о так называемом бэкстопе в Северной Ирландии (ТАСС).

Два предложения содержат три заимствования (Brexit, билль, бэкстоп), которых вполне можно было бы избежать, если бы автор цитируемого текста использовал языковые средства русского языка. За 3 года существования в русском языке термин брэкзит стал понятным среднестатистическому россиянину: более $50 \%$ респондентов смогли объяснить значение этого англицизма. Однако некоторые респонденты ответили, что брэкзит - это вblход Англии из Евросоюза, выборы, выход откуда-то, референдум, отставка.

Слово бэкстоп (букв. «ограничитель обратного хода» или «оказывать поддержку»; обозначает политику сохранения Северной Ирландии в составе Таможенного союза ЕС и поддержки единого европейского рынка после брэкзита) новое в русском языке и, согласно проведенному исследованию, вызывает недопонимание более чем у $90 \%$ респондентов. 
При этом, пытаясь объяснить значение данного англицизма, участники эксперимента зачастую опирались на знание английского языка, однако данный термин обладает дополнительными коннотациями, которые нельзя передать с помощью прямого перевода слова. Среди ответов респондентов встречались: дать заднюю, забор, возврат назад, шаг назад, отсутствие жесткой гранииы.

Слово билль, употребленное вместо русского и вполне уместного законопроект, смогли объяснить менее $50 \%$ респондентов (большинство из них - это информанты 4655 лет). Следует отметить, что брэкзит и бэкcmon все чаще транслитерируются на русский язык в тексте новостей, отражая их адаптацию в русской речи.

Еще одно новое заимствование, относящееся к политической сфере, шатдаун (англ. government shutdown - «приостановка работы правительства США») является отражением исключительно американской действительности и способно вызвать непонимание у носителя русского языка. Рассмотрим следующие примеры:

(3) Президент США Дональд Трамп предположил, что демократы намеренно выдвигают «плохие предложения» по строительству стены на границе с Мексикой, чтобы спровоцировать очередной шатдаун (RT).

Как показал проведенный нами эксперимент, значение англицизма шатдаун смогли объяснить лишь $20 \%$ респондентов, 10 \% попытались дать его перевод, опираясь на знание английского языка (выключение, заткнись (перепутано с shut up), отключение), однако он не соответствует тому значению, которое имеет данный термин в контексте новостей о событиях в США. Среди ответов респондентов встречались и такие, как налоговый откат от президента, экономическая ситуациия в США, «ни шагу назад».

Можно предположить, что употребление термина шатдаун в заголовке интернетновостей, например

(4) Белый дом допустил возможность нового шатдауна через неделю (Ведомости),

увеличивает шансы на то, что пользователь, не знающий толкования этого слова, перейдет по ссылке в надежде получить разъяснения по интересующей его теме.

Отметим, что некоторые СМИ предпринимают попытку дать пояснения используемому в тексте новостей термину шатдаун, что, несомненно, облегчает для читателя понимание текста. Например:

(5) Президент Соединенных Штатов республиканец Дональд Трамп заявил 10 февраля, что позиция представителей Демократической партии ведет страну к новому шатдауну - временному закрытию федеральных учреждений (Известия);

(6) 22 декабря правительство Соединенных Штатов частично приостановило работу - причиной шатдауна стало нежелание демократов выделять средства в бюджете на строительство стены на границе с Мексикой (Известия).

Проанализировав статистику запросов пользователей Google на сервисе Google Trends, мы установили, что в период активного упоминания российскими СМИ англоязычных терминов брэкзит (началом данного периода можно считать референдум в Великобритании по выходу из Европейского союза 23 июня 2016 г.) и шатдаун (началом данного периода стоит считать 22 декабря 2018 г., когда демократы сената США отказались утверждать вариант бюджета, в который Д. Трамп включил 5 миллиардов долларов на строительство стены с Мексикой) уровень популярности запросов пользователей, желающих выяснить «Что такое брэкзит?» и «Что такоешатдаун?», увеличился с 0 до 75 и с 0 до 100 баллов соответственно. Данная статистика является доказательством того, что использование в СМИ прямых заимствований из английского языка влечет за собой затрудненное понимание аудиторией сути новостного сообщения.

\section{Выводы}

Результаты проведенного исследования позволяют сделать следующие выводы:

1) потенциальные реципиенты информации не понимают значения ряда употребляемых в СМИ англицизмов, что является причиной затрудненного восприятия отдельных политических новостей и, как результат, политической неосведомленности в целом;

2) знание английского языка не всегда помогает пониманию употребляемых в СМИ 


\section{МАТЕРИАЛЫ И СООБЩЕНИЯ}

англицизмов, поскольку нередко заимствуется только одно значение иностранного слова, возможно незнакомое адресату, а буквальный перевод слова приводит к неверному толкованию и интерпретации сообщения в целом, что негативно сказывается на качестве получаемой информации;

3) точность понимания значения иностранных слов, звучащих в СМИ, варьируется в зависимости от возраста, интересов адресата, поэтому для предотвращения коммуникативных неудач предлагается избегать (по возможности) употребления англицизмов в новостных сообщениях, направленных на массовую аудиторию;

4) использование заимствований, значение которых непонятно адресату, заключает в себе коммуникативные риски, связанные с невозможностью реализовать воздействующую и информационную функции, а именно они являются основополагающими во взаимодействии СМИ с аудиторией.

Результаты проведенного опроса являются свидетельством очевидных коммуникативных рисков. Непонимание аудиторией употребляемых в СМИ англицизмов приводит к неоднозначному восприятию освещаемой проблемы и, как следствие, к невозможности полноценного диалога с населением, достижения понимания между властью и обществом в социально-политической сфере.

Для преодоления негативного влияния потока заимствований в современной языковой ситуации необходимо вести просветительскую работу, в том числе СМИ, подробно объясняя значения новых слов. Носитель языка должен свободно ориентироваться в потоке новых слов, при этом совершенствуя языковые навыки в процессе коммуникации на родном языке. Безупречное владение родным языком и осознание ценности национального языка и культуры служат формированию хорошего языкового вкуса и способны сдерживать негативное влияние заимствований на речевую культуру социума.

\section{СПИСОК ЛИТЕРАТУРЫ}

Апресян Ю. Д., 1992. О состоянии русского языка (материалы почтовой дискуссии) // Русская речь. № 2. С. 48-57.
Вепрева И. Т., 2006. О кодифицированной норме в современной культурно-речевой ситуации : Норма и мода // Русский язык сегодня. М. : Ин-т рус. яз. им. В.В. Виноградова. Вып. 4 : Проблемы языковой нормы. С. 116-117.

Граудина Л. К., Дмитриева О. Л., Новикова Н. В., Ширяев Е. Н., 1995. Мы сохраним тебя, русская речь. М. : Наука. 125 с.

Гуляева Е. В., 2018. Коммуникативные риски, связанные с глобальным английским // Известия ВГПУ. Филологические науки. Серия: Языкознание. № 10. С. 145-148.

Гуторова Н. С., 2015. Ассимилированные языковые единицы, или собственно заимствования // Национальная ассоциация ученых. № 9, ч. 4. C. 101-103.

Карасик В. И., 2002. Языковой круг: личность, концепты, дискурс. Волгоград : Перемена. 477 с.

Китанина Э. А., 2005. Прагматика иноязычного слова в русском языке : автореф. дис. ... д-ра филол. наук. Краснодар. 43 с.

Китанина Э. А., Божинская Т. Л., 2009. Проблема неоднородности общества и социальная дифференциация языка на рубеже XXXXI вв. // Теория и практика общественного развития. № 3-4. С. 233-240.

Козырев В. А., Черняк В. Д., 2007. Свое и чужое: заимствованное слово в современной речи // Вестник Герценовского университета. № 3 (41). C. 54-59.

Крысин Л. П., 2004. Русское слово, свое и чужое: исследования по современному русскому языку и социолингвистике. М. : Яз. слав. культуры. 883 с.

Морковкин В. В., Морковкина А. В., 1997. Русские агнонимы (слова, которые мы не знаем). М. : Ин-т рус. яз. им. А.С. Пушкина. 416 с.

Пентина А. Ю., Черняк В. Д., 2015. Агнонимичная политическая лексика в тезаурусе молодежи: перспективы диалога // Политическая лингвистика: проблематика, методология, аспекты исследования и перспективы развития научного направления : материалы Междунар. науч. конф. (Екатеринбург, 27 нояб. 2015 г.). Екатеринбург : Изд-во УГПУ. С. 188-192.

Сиротинина О. Б., 2013. Система, узус и риски их изменений // Вестник Волгоградского государственного университета. Серия 2, Языкознание. № 3 (19). С. 7-12.

Черняк В. Д., 2003. Агнонимы в лексиконе языковой личности как источник коммуникативных неудач // Русский язык сегодня. М. : Азбуковник. Вып. 2 : Активные языковые процессы конца ХХ века. С. 295-304.

Черняк В. Д., 2005. «Зоны риска» в лексиконе языковой личности: к основаниям коммуникативных 
неудач // Вестник ТГПУ. Серия: Гуманитарные науки (филология). Вып. 3 (47). С. 96-100.

\section{ИСТОЧНИКИ И СЛОВАРИ}

Академик.ру - Академик.ру. Словари и энциклопедии. URL: https://academic.ru/ (дата обращения: 10.02.2019)

Ведомости - Белый дом допустил возможность нового шатдауна через неделю // Ведомости. URL: https://www.vedomosti.ru/politics/news/ 2019/02/10/793731-shatdaun (дата обращения: 10.02.2019).

Известия - Трамп обвинил демократов в провоцировании очередного шатдауна // Известия. URL: https://iz.ru/844239/2019-02-11/trampobvinil-demokratov-v-provotcirovaniiocherednogo-shatdauna (дата обращения: 11.02.2019).

РБК - СМИ узнали о тайном обсуждении отсрочки Brexit в британском правительстве // PocБизнесКонсалтинг. URL: https://www.rbc.ru/ politics/06/02/2019/5c5a70d39a79472724598bea (дата обращения: 06.02.2019).

$T A C C$ - Тони Блэр считает, что Brexit без сделки угрожает мирному процессу в Северной Ирландии // TACC. URL: https://tass.ru/mezhdunarodnayapanorama/6098615 (дата обращения: 06.02.2019).

$R T$ - Трамп предположил, что демократы намеренно добиваются шатдауна // Russia Today. URL: https://russian.rt.com/world/news/601380tramp-demokraty-shatdaun (дата обращения: 12.02.2019).

\section{REFERENCES}

Apresyan Yu.D., 1992. O sostoyanii russkogo yazyka (materialy pochtovoy diskussii) [About the State of the Russian Language (Materials of the Post Discussion)]. Russkaya rech [Russian Speech], no. 2, pp. 48-57.

Vepreva I.T., 2006. O kodificirovannoy norme v sovremennoy kul'turno-rechevoy situacii: Norma i moda [On the Codified Norm in the Modern Cultural and Speech Situation: Norm and Fashion]. Russkiy yazyk segodnya [Russian Language Today]. Moscow, Institut russkogo yazyka im. V.V. Vinogradova. Iss. 4. Problemy yazykovoy normy [Issues of the Language Norm], pp. 116-117.

Graudina L.K., Dmitrieva O.L., Novikova N.V., ShiryaevE.N., 1995. My sohranim tebya, russkaya rech [We Will Save You, Russian Speech]. Moscow, Nauka Publ. 125 p.
Gulyaeva E.V., 2018. Kommunikativnye riski, svyazannye s globalnym angliyskim [Communication risks associated with global English]. Izvestiya VGPU. Filologicheskie nauki. Seriya: Yazykoznanie [Izvestia of the Volgograd State Pedagogical University. Linguistics], no. 10, pp. 145-148.

Gutorova N.S., 2015. Assimilirovannye yazykovye edinicy, ili sobstvenno zaimstvovaniya [Assimilated Linguistic Units, or Properly Borrowings]. Natsionalnaya assotsiatsiya uchenykh, no. 9, pt. 4, pp. 101-103.

Karasik V.I., 2002. Yazykovoy krug: lichnost, koncepty, diskurs [Language Circle: Personality, Concepts, Discourse]. Volgograd, Peremena Publ. 477 p.

Kitanina Ye.A., 2005. Pragmatika inoyazychnogo slova v russkom yazyke: avtoref. dis.... d-ra filol. nauk [Pragmatics of a Foreign Language Word in Russian. Dr. philol. sci. abs. diss.]. Krasnodar. 43 p.

Kitanina Ye.A., Bozhinskaya T.L. 2009. Problema neodnorodnosti obshchestva i socialnaya differentsiatsiya yazyka na rubezhe XX-XXI vv. [Problem of Heterogeneity of Society and Social Differentiation of Language on the Border of $20^{\text {th }}-21^{\text {st }}$ Centuries]. Teoriya $i$ praktika obshchestvennogo razvitiya [Theory and Practice of Social Development], no. 3-4, pp. 233-240.

Kozyrev V.A., Chernyak V.D., 2007. Svoe i chuzhoe: zaimstvovannoe slovo v sovremennoy rechi [Native and Foreign Phenomena: Borrowings in Modern Speech]. Vestnik Gercenovskogo universiteta [Scientific Journal of Herzen University], no. 3 (41), pp. 54-59.

Krysin L.P., 2004. Russkoe slovo, svoe i chuzhoe: issledovaniya po sovremennomu russkomu yazyku i sociolingvistike [Russian Word, Native and Foreign One: Research on the Modern Russian Language and Sociolinguistics]. Moscow, Yazyki slavyanskoy kultury Publ. 883 p.

Morkovkin V.V., Morkovkina A.V.. 1997. Russkie agnonimy (slova, kotorye my ne znaem) [Russian Agnonyms (Words We Don't Know)]. Moscow, Institut russkogo yazyka im. A.S. Pushkina. 416 p.

Pentina A.Yu., Chernyak V.D., 2015. Agnonimichnaya politicheskaya leksika $\mathrm{v}$ tezauruse molodezhi: perspektivy dialoga [Political Vocabulary Based on Agnonimation in the Youth Thesaurus: Dialogue Prospects]. Politicheskaya lingvistika: problematika, metodologiya, aspekty issledovaniya i perspektivy razvitiya nauchnogo napravleniya: materialy Mezhdunar. nauch. konf. (Ekaterinburg, 27 noyab. 2015 g.) [Political Linguistics: Problems, Methodology, Aspects of Research and Prospects for the Development of Scientific Direction. Proceedings of the International 
Scientific Conference(Yekaterinburg, November 27, 2015)]. Yekaterinburg, Izd-vo UGPU, pp. 188-192. Sirotinina O.B., 2013. Sistema, uzus i riski ih izmeneniy [System, Usage and Risks of Their Changes]. Vestnik Volgogradskogo gosudarstvennogo universiteta. Seriya 2. Yazykoznanie [Science Journal of Volgograd State University. Linguistics], no. 3 (19), pp. 7-12.

Chernyak V.D., 2003. Agnonimy v leksikone yazykovoy lichnosti kak istochnik kommunikativnyh neudach [Agnonyms in the Lexicon of a Linguistic Persona as a Source of Communicative Failures]. Russkiy yazyk segodnya [Russian Language Today]. Moscow, Azbukovnik Publ., Vyp. 2: Aktivnye yazykovye protsessy kontsa XX veka [Vol. 2. Active Language Processes of the Late Twentieth Century], pp. 295-304.

Chernyak V.D., 2005. «Zonyriska» v leksikone yazykovoy lichnosti: k osnovaniyam kommunikativnyh neudach ["Risk Zones" in the Lexicon of a Linguistic Persona: To the Bases of Communicative Failures.]. Vestnik TGPU. Seriya: Gumanitarnye nauki (filologiya) [Tomsk State Pedagogical University Bulletin], iss. 3(47), pp. 96-100.

\section{SOURCES}

Akademik.ru. Slovari i entsiklopedii [Academic.ru. Dictionaries and Encyclopaedias]. URL: https:// academic.ru/ (accessed 10 February 2019).
Belyy dom dopustil vozmozhnost novogo shatdauna cherez nedelyu [The White House Assumed the Possibility of a New Shutdown in a Week]. Vedomosti. URL: https://www.vedomosti.ru/ politics/news/2019/02/10/793731-shatdaun (accessed 10 February 2019).

Tramp obvinil demokratov v provotsirovanii ocherednogo shatdauna [Trump Accused the Democrats of Provoking Another Shutdown]. Izvestiya. URL: https://iz.ru/844239/2019-02-11/tramp-obvinildemokratov-v-provotcirovanii-ocherednogoshatdauna (accessed 11 February 2019).

SMI uznali o taynom obsuzhdenii otsrochki Brexit v britanskom pravitelstve [Media Learned About the Secret Discussion of the Postponement of Brexit in the British Government]. RosBiznesKonsalting. URL: https://www.rbc.ru/ politics/06/02/2019/5c5a70d39a79472724598bea (accessed 6 February 2019).

Toni Bler schitaet, chto Brexit bez sdelki ugrozhaet mirnomu protsessu v Severnoy Irlandii [Tony Blair Believes That a No-Deal Brexit Threatens the Peace Process in Northern Ireland]. TASS. URL: https://tass.ru/mezhdunarodnayapanorama/6098615 (accessed 6 February 2019).

Tramp predpolozhil, chto demokraty namerenno dobivayutsya shatdauna [Trump Suggested That the Democrats Are Deliberately Seeking a Shutdown]. Russia Today. URL: https://russian. rt.com/world/news/601380-tramp-demokratyshatdaun (accessed 12 February 2019).

\section{Information About the Authors}

Evgenia V. Gulyaeva, Candidate of Sciences (Philology), Head of the Department of Linguistics and Intercultural Communication, Volgograd Institute of Management, branch of the Russian Presidential Academy of National Economy and Public Administration (RANEPA), Gagarina St, 8, 400066 Volgograd, Russia,guevgenia@yandex.ru,https://orcid.org/0000-0003-1605-8576

Maria V. Denisenko, Candidate of Sciences (Philology), Associate Professor, Department of Linguistics and Intercultural Communication, Volgograd Institute of Management, branch of the Russian Presidential Academy of National Economy and Public Administration (RANEPA), Gagarina St, 8, 400066 Volgograd, Russia, makarova-mw@yandex.ru, https://orcid.org/0000-0002-8160-9517

Irina S. Nikitina, Candidate of Sciences (Philology), Associate Professor, Department of Linguistics and Intercultural Communication, Volgograd Institute of Management, branch of the Russian Presidential Academy of National Economy and Public Administration (RANEPA), Gagarina St, 8, 400066 Volgograd, Russia, ir-rina07@mail.ru, https://orcid.org/0000-0002-2977-0178

\section{Информация об авторах}

Евгения Вячеславовна Гуляева, кандидат филологических наук, заведующая кафедрой лингвистики и межкультурной коммуникации, Волгоградский институт управления - филиал Российской академии народного хозяйства и государственной службы при Президенте РФ, ул. Гагарина, 8, 400066 г. Волгоград, Россия, guevgenia@yandex.ru, https://orcid.org/0000-0003-1605-8576 
Е.В. Гуляева, М.В. Денисенко, И.С. Никитина. Употребление заимствований в современных СМИ

Мария Валерьевна Денисенко, кандидат филологических наук, доцент кафедры лингвистики и межкультурной коммуникации, Волгоградский институт управления - филиал Российской академии народного хозяйства и государственной службы при Президенте РФ, ул. Гагарина, 8, 400066 г. Волгоград, Россия, makarova-mw@yandex.ru, https://orcid.org/0000-0002-8160-9517

Ирина Сергеевна Никитина, кандидат филологических наук, доцент кафедры лингвистики и межкультурной коммуникации, Волгоградский институт управления - филиал Российской академии народного хозяйства и государственной службы при Президенте РФ, ул. Гагарина, 8, 400066 г. Волгоград, Россия, ir-rina07@mail.ru, https://orcid.org/0000-0002-2977-0178 